species of Ceriornis has its home. This is Blyth's Tragopan (C. blythi), first discovered in the Mishmi Hills by the late Dr. Jordin during his excursion to Assam in 1869 , and subsequently met with by Major Godwin-Austen in the Naga Hills, south of the Brahmaputra. Blyth's Tragopan has likewise been once exhibited alive in the Zoological Society's Gardens, an adult male of this fine bird having been presented to the collection by Major Montagu in I 870 . Little, however, is yet known of it.

The fifth and last species of Tragopan, which we now figure (Fig. 25), from an example lately acquired by the Zoological Society, is still more rare and little known than the four above-mentioned members of the genus. Cabot's Tragopan, as it is called, was described in 1857 by the late Mr. Gould, and subsequently figured in his great illustrated work on the Birds of Asia. Its habitat is SouthEastern China, but little is yet known of its' exact range. The only naturalist who has met with it in its native wilds is the celebrated Chinese explorer, M. le Pêre David. M. David, in his "Oiseaux de la Chine," tells us that he found this fine Gallinaceous bird rather common in the wooded mountainous range which separates the provinces of Fokien and Kiangsi, when he traversed this district in the autumn of 1873 , and obtained many examples for the French National Collection.

So far as has been recorded, the male specimen of this Tragopan, received by the Zoological Society in April last is the only example that has reached Europe alive.

\section{THE ROT IN SHEEP, OR THE LIFE-HISTORY OF THE LIVER-FLUKE}

$T$ HE winter of 1879 -80 was marked by a widely-spread outbreak of the liver-rot amongst our sheep. The losses during that winter were estimated at three million sheep, or about one-tenth of the total number in the United Kingdom, and during the following winter the losses were equally severe. It had long been known that the disease was due to the presence in large numbers of a parasite called the liver-fluke (Fasciola hepatica) in the liver of the affected animals, and that the parasite invaded sheep or sometimes other animals allowed to feed on wet pastures, and especially on flooded ground. But notwithstanding that the question had been repeatedly investigated by numerous zoologists, including Prof. Leuckart, so well known for his researches on parasites, the manner in which the disease was incurred remained a. complete mystery. It was known indeed that the animals most nearly allied to the liver-fluke, the digenetic Trematodes, presented an alternation of generations, and that they possessed larval forms infesting various species of molluscs. These nurse-forms, as they are called, produce internally larvæ, usually tailed, known as cercariæ, which leave the nurse and encyst themselves in some other mollusc or in aquatic insect larvæ, \&c., and remain there quiescent, only reaching maturity if swallowed together with the animal harbouring them by some suitable vertebrate host. Such is a typical instance of the development of a trematode with alternation of generations, but there is a good deal of variety in the life-histories of the different species. It was supposed that the liver-fluke had a somewhat similar life-history, but all attempts to discover what mollusc served as intermediate host had been fruitless.

The Royal Agricultural Society of England was induced by the heavy losses of sheep in 1879-80 to offer a grant for the investigation of the natural history of this most destructive parasite. I undertook the research, and the results of my work during the summer and autumn of i 880 were published in the Journal of the Society for April r881. Certain slugs had been suggested as probable bearers of the larval form of the liver-fluke, and I was able to show that these conjectures had little evidence to support them, and suggested that Limnous truncatulus was really the intermediate host, or at least one of the intermediate hosts of the liver-fluke. For on the Earl of Abingdon's estate at Wytham, I examined thoroughly a clearly circumscribed area of infection situated on the side of a hill far above the reach of floods, and found that almost the only species of water-snail occurring on the ground was Limnceus truncatulus, found in a boggy spot. This contained an interesting form of cercaria, produced in a cylindrical redia, or nurse-form provided with digestive tract.

The free cercaria had a body of oval form, about 0.3 $\mathrm{mm}$. ( $\frac{3}{80}$ in.) in length, but was of very changeable shape. The two suckers characteristic of the adult forms of the family of the Distomidae were of nearly equal size, the oral sucker about terminal, and the ventral sucker near the middle of the ventral surface. The anterior part of the body was covered, at least in the most mature examples, with exceedingly minute spines. But the most striking character of the cercaria was due to lobed lateral masses extending the whole length of the body on each side of the middle line. These lobed masses were an opaque white from the multitude of granules composing them. The cercaria had a tail, which, when fully extended, was more than twice the length of the body. It was exceedingly active, but soon came to rest, showing a strong tendency to encyst itself on surrounding objects. It contracted so as to assume a rounded form, and exuded a mucous substance, containing numerous opaque granules derived from the lateral masses described, which were thus shown to be a special larval organ, producing the substance of which the cyst was composed. The tail continued to wag violently, and was at length pinched off as it were by the hardening wall of the cyst. The cysts were snowy white by reflected light, but on rupturing them the included larvæ was found to be quite transparent. I had a few months previously seen a sheep which I had the best possible reason for knowing to be infected with flukes, wandering over the boggy spot from which the snail containing the cercaria came, and the presence of so highly developed an organ for the production of the substance of the cyst in a cercaria which encysted on any plants at hand, seemed to indicate that here was the cercaria of the liver-fluke, and it has since been proved that such was the case. Moreover, I had collected evidence from independent sources, which rendered it probable that the parasite was taken up by the sheep while grazirg from the damp roots of grass, most likely in the encysted condition.

Of this cercaria I wrote at the time as follows :--" The structure and habits of this cercaria render it possible that it may prove to be the larva of Fasciola hepatica, but want of material has prevented my testing the question by giving the cyst to rabbits. I intend, however, to pursue this case further."

Accordingly, during the summer of $188 \mathrm{I}$, I endeavoured to procure $\mathcal{L}$. truncatulus in order to put my strong suspicion to the test of experiment. But I was unfortunately unable to find any, even in the localities where I had found it during the previous year. In my search I had on many occasions the skilled assistance of my friend and colleague $\mathrm{Mr}$. W. Hatchett Jackson, but we never found any other trace of this species than the empty shells. The localities for the snail mentioned by Whiteave in his paper on the mollusca inhabiting the neighbourhood of Oxford, were searched, but without success. My friends at a distance were appealed to, but were unable to assist me. There can be little doubt that the freedom of sheep near Oxford from the liver-rot during last winter was directly connected with the real scarcity of this snail. This year, however, there were floods on the Isis in July, and L. truncatulus was brought down by the water in vast quantities, probably from marshy ground far up the river. So numerous were they that I repeatedly obtained 
as many as 500 specimens at a single sweep of a small hand-net. The low-lying meadows near the river were covered with the flood waters, and when these subsided the snails were left scattered broadcast over the fields. The snail is almost the smallest species of Limnæus; the variety which I found so abundantly was only a quarter of an inch long when fully grown. Although it is a water-snail it lives much out of water. My observations have convinced me that the individuals left by floods on the fields continue to live out of water so long as the ground is moist. Their numbers are recruited by others which crawl out of neighbouring ditches or streams. If a drought occurs they become dormant, but unless too long continued they revive with the first shower of rain.

On discovering these snails I immediately started infection experiments with them, and was at once successful. The adult fluke in the liver of the sheep or other mammalian host produces vast quantities of eggs. So prolific is it that I have estimated the number produced by each fluke to be at least several hundred thousand. The eggs pass with the bile into the intestines and are distributed over the fields with the manure. If the eggs fall on to wet ground, or are washed into a ditch, development continues, and after a time, the length of which depends upon the temperature, embryos are hatched out of the eggs. For the purpose of my infection experiments I obtained eggs from the livers of affected sheep, and kept them in water until the embryos were hatched, and then transferred them to vessels containing the snails to be experimented upon.

The embryo of the liver-fluke has the shape of an elongated cone with rounded apex; its average length is $125 \mathrm{~mm}$., or about $\mathrm{I} / 200$ of an inch; its breadth at the anterior end about one-fifth of this. The broader end or base of the cone is always directed forwards, and in the centre of this a short retractile head-papilla. The whole of the surface, with the exception of the head-papilla, is covered with very long cilia, by means of which it swims, with head-papilla drawn in, swiftly and restlessly through the water. It is exceedingly active; sometimes it goes rapidly forwards, and then rotates on its longitudinal axis, just turning a little from side to side as if searching for something. At other times, by curving its body, it sweeps round in circles, or, curving itself still more strongly, spins round and round without moving from the spot. The cilia are carried by an outer layer of flattened ectoderm cells arranged in five or six transverse rings around the body, and are of the same length over the whole of the surface. The first ring is composed of four cells arranged around the papilla, and these are thicker than the other outer cells, often forming projections at the side of the embryo and resembling epaulets. Beneath these ciliated cells is the body wall proper, and within this are a number of delicate vesicular cells - the germinal cells. Behind the head-papilla is a rudimentary digestive tract. The body-wall contains, near the anterior end, a double eye-spot, composed of crescentic masses of dark pigment, placed with their convex sides turned towards each other.

When the embryo, in moving through the water, comes in contact with any object, it pauses for a moment, and feels about as if trying to discover its nature, and if not satisfied darts off hastily again. But if the object be a Limnceus truncatulus it at once begins to bore. Under ordinary conditions the head-papilla of the embryo is short and blunt, but as soon as the animal begins to bore it becomes longer, conical, and pointed. The embryo spins round on its axis, the cilia working vigourously and pressing the embryo against the surface of the snail. This pressure is increased by the body of the embryo being alternately drawn up and then suddenly extended. As the papilla sinks further into the tissues of the snail it becomes longer and longer until it reaches five times its original length, and the tissues of the snail are forced apart as if by a wedge, leaving a gap through which the embryo squeezes its way into the snail.

The embryo will not bore into all snails alike; the only other species which I have found it bore into from without is Limnceus pereger, and even here the specimens have always been such as were still very small. I have found embryos enter certain other snails, such as Planorbis, but only from eggs which had been swallowed by the snail and had been hatched in the digestive tract. This difference seems to be due to an instinctive choice on the part of the embryo, rather than to a greater softness of the tissues in Limnces truncatulus. The tissues of Physa fontinalis, for instance, appear to be equally soft, but I have found that if these two species are placed in a small bulk of water with a very large number of embryos, the Limnaei will be found on dissection to contain fifty or more embryos, whilst the Physa will be entirely free from them.

But although theinstinct of the embryo seemingly prompts it to enter the right snail, it does not teach it to discriminate between the different parts of the snail's body, for I have found as many as a dozen embryos within the substance of the foot of a single Limnaus truncatulus. Such a position of course is not favourable to further development of the embryos, which, thus gone astray, soon perish.

The natural place for the further development of the embryo appears to be the pulmonary chamber, but they may also be found in the body cavity. Once safely lodged in the suitable locality, the embryo undergoes a metamorphosis. It loses the external layer of ciliated cells and changes from the conical to an elliptical shape. The eye-spots usually become detached, but they, as well as the head-papilla persist, showing the identity of the young sporocyst - for so it must now be called-with the embryo of the liver-fluke. The active embryo has degenerated into a mere brood-sac, in which the next generation is produced. The sporocyst increases rapidly in size, the round, clear cells contained within it increase in number, partly perhaps owing to the division of the germinal cells of the embryo, but also owing to a multiplication and subsequent detachment of the cells lining the inside of the body wall. As growth proceeds the contents of the sporocyst arrange themselves into round balls of cells, the germs of the secont generation These germs increase in size, an 1 assume first an oval and then an oblong shape, whilst a delicate cuticle is formed upon the surface. At one end a number of cells are arranged to form a spherical pharynx, which leads into a blind digestive sac. A little behind the pharynx the surface of the body is raised into a ridge, forming a ring surrounding the anterior end, whilst near the opposite end two short processes grow out. The germ has now become a redia, as the brood-sac or nurse-form provided with pharynx and intestine is called. The adult sporocyst is sac-shaped and reaches the length of $6 \mathrm{~mm}$. : it usually contains one or two redize nearly ready to leave, together with two or three larser and several smaller germs. There is another method of increase during the sporocyst stage, namely, by the division of a sporocyst into two others by a constriction separating the original one into two smaller ones. This method of multiplication, however, does not appear to be frequent in this species.

When the redia is ready to come forth, it breaks through the wall of the sporocyst, and the wound caused by its forcible exit immediately closes up, and the remaining germs continue to develop. The injury done by the parasites to the snails causes a serious mortality amongst them, especially at the time the rediæ begin to leave the sporocysts, for the former are much more active than the almost inert sporocysts, and migrate from the pulmonary chamber into the other organs of the snail, and particularly into the liver, upon which they feed. The rediæ can be observed with the microscope, through the trans 
parent shell, moving in the snail's liver. So great is the injury done, that in the laboratory, at any rate, very few snails survive three weeks from infection.

The redia increases in size, and may ultimately reach the length of $I^{\prime} 3 \mathrm{~mm}$. or about one-twentieth of an inch. It resembles in every respect the redia I formerly described as found in the same snail at Wytham. Its contents of spherical cells arranged themselves into round germs as in the sporocyst, though I was able in this case to observe the formation of a gastrula. The germs at first were spherical, they then become oval, and afterwards they elongate still more, whilst one end becomes narrower than the other. The narrower end is partially constricted from the remainder, and, becoming long and slender, forms the tail of the cercaria, whilst the rest of the germ becomes the body. A sucker appears at the anterior end, and another of nearly equal size at the middle of the ventral surface of the flattened body, whilst within a digestive tract appears. This digestive tract is simply forked, and presents no trace of the lateral branches so characteristic of the adult.

The adult redia contains about a score of germs, but these are in very different stages of development. There are generally two or three nearly mature, the others in various stages down to small spheres of cells. Close to the raised ring surrounding the body of the cercaria there is a small opening as in all redix, by means of which the cercariae are destined to be liberated one by one as they come to maturity.

But not all the rediae produce cer cariae, for they sometimes produce other rediae, and these daughter-rediae then give rise to cercariae. These latter, therefore, sometimes only appear as the fourth generation in the snail, and in one set of experiments I had reason to believe that no cercariae appeared earlier. It will thus be seen that a single embryo may give rise to more than a thousand cercariae.

In April of the Ipresent year Leuckart published a paper in the "Archiv für Naturgescbichte," where he described certain experiments on the development of the liver-fluke. He believed that Limnaeus pereger was the intermediate host, and had succeeded in infecting this species, though he had failed to rear the redia beyond the stage in which the contents were forming into spores. He had, however, obtained a number of $L$. truncatulus from a friend, and had found in them three different sorts of rediae. One of these contained tail-less distome larvae, and not withstanding that the characters of the redia were very different from those reared from the embryo of the liverfluke, he believed the conjecture that this was really the larva of the liver-fluke to be entirely justified until further results were obtained. The second form he considered migbt possibly be related to the liver-fluke, but the probability was far less than in the case of the tailless form. In his description of the third form I at once recognised the cercaria I had already found and suggested as the larva of the liver-fluke. Leuckart, however, did not consider that there could be any connection, because he failed to detect any spines on the surface of the body such as we should expect, and on account of the lobed lateral organs, which he thought might be the vitellaria of the adult.

I wrote a report of my own results as described above, giving them, however, in greater detail, for the October number of the Journal of the Royal Agricultural Society. This report was sent to the printer on the Ist of September, and a fortnight later received a revision which was merely verbal.

On October 9 th a paper by Leuckart appeared in the Zoologischer Anzeiger, a periodical which gives rapid publication to important papers. In this Leuckart extends his former results, and states that he too has reared the cercaria of the liver-fluke in L. truncatulus, and finds that it is the form with the lobed lateral organs which he had already seen, and supposed to have no connection with the liver-fluke. It will be seen, therefore, that the cercaria of the liver-fluke is really the form found by me in Limnaeus truncatulus at Wytham, and described in the Royal Agricultural Society's Journal for 188I. It is interesting to see this result confirmed, not only by my own experiments, but also by Leuckart's independent investigations.

Leuckart has not been able to find any trace in the cercaria of the spines which cover the surface of the adult fluke. He has, however, found in the cells of the cercaria small rod shaped bodies closely resembling bacteria in shape and size, and thinks they may eventually be arranged in bundles and form the spines of the adult. But I have already stated that the anterior part of the body of the cercaria is covered with exceedingly fine spines, which can, however, only be seen in the most mature examples. The reason why Prof. Leuckart could not observe these spines was possibly because. his examples were scarcely so mature. The rod-like bodies he mentions have certainly no connection with the spines of the adult. He states that they have never yet been found in other cercariae. I may perhaps be allowed to say that they have been described by three different observers, first by Wagener, then by Filippi in the cercaria of Amphistoma subclavatum, and by myself in the cercaria of the liver-fluke (described in April, I88r.

For further details of the structure and natural history of the liver-fluke, as well as the discussion of preventive measures, I may refer to my reports in the Journal of the Royal Agricultural Society.

University Museum, Cxford, October I 3

A. P. THOMAS

\section{A NEW CASE OF COMMENSALISM}

CASES of Commensalism amongst the higher animals are rare. Those of the Prairie dog and Rattlesnake, in North America, and of the Burrowing $\mathrm{Owl}$ and Vizcacha in the Pampas of Buenos Ayres, are, however, familiar instances of it. The newly issued volume of the "Transactions and Proceedings of the New Zealand Institute" contains a communication from Prof. von Haast on a new and interesting case of two very different animals owning a common habitation.

One of these creatures being exceedingly scarce and little known, a few details upon this curious subject will be the more acceptable.

In December I880, Mr. Reis shek (a correspondent of Prof. v. Haast) paid a visit to a cluster of islands, called the "Chickens" situated East of Wangarei Bay on the East coast of the North Island of New Zealand. These Islands are now uninhabited by man but contain numerous remains of Maori Pahs and Kitchen-Middens showing that they were formerly much resorted to by the Natives.

The present inhabitants consist of certain species of birds, of which Mr. Reischek furnishes a list, and of multitudes of the celebrated Tuxtara Lizard (Sphenodon bunctatus)-one of the most anomalous forms of the Lacertian order, if, indeed, we are permitted by Dr. Günther to call it a Lizard at all.

Of these birds certain Petrels (namely Procellaria gouldi, $P$. Cooki, and Puffinus gavnus) live in holes dug out by the Tuataras and keep apparantly on the best terms with them. The Tuatara, we are told, excavates its hole mostly on the western slopes of the Islands. The entrance to its chamber is generally four or five inches in diameter, and the passage leading to it often two or three feet long, first descending and then ascending again. The chamber itself is about one foot and a half long, by one foot wide and six inches high and is lined with grass and leaves. The Petrels and Tuataras have their nests separately, one on each side of the entrance, so that they in no way interfere with one another. 